\title{
ANALISIS KEBUTUHAN PELATIHAN DI PASAR KEBON EMPRING BERDASARKAN TRAINING NEED ASSESSMENT
}

\author{
Maelani Fitri ${ }^{1}$, Wihardiyani ${ }^{2}$ \\ Universitas Gajah Mada Pasca Sarjana Magister Kajian Pariwisata \\ maelani.fitri86@gmail.com ${ }^{1}$ \\ diyanwihar@gmail.com ${ }^{2}$
}

\begin{abstract}
Human resource development is a way to innovate, improve the abilities possessed by each individual for self-development. Human resource development provides various positive impacts for individuals and related institutions. Kebon Empring Market is a new tourist destination managed by the Bintaran Wetan community that offers a variety of traditional culinary delights. The purpose of writing this paper is to find out what needs are needed in developing tourism in the Kebon Empring Market using a SWOT analysis by applying the Training Needs Assessment strategy proposed by Barbazette (2006) with three stages, namely; Information gathering is done by interviewing the management and document study, 2 . Information analysis using SWOT analysis (Strength, Weakness, Opportunity, Threats), 3. Determining the training plan.
\end{abstract}

Key words need analysis, kebon empring market, Training Need Assessment

\section{PENDAHULUAN}

Kebutuhan untuk berwisata dewasa ini menjadi suatu hal yang penting bagi masyarakat yang didukung oleh perkembangan teknologi. Mudahnya akses informasi dan transportasi menjadi faktor pendukung masyarakat untuk melakukan kegiatan wisata. Kemudahan ini kemudian menunjang pertumbuhan pariwisata yang kemudian dijadikan sebagai bisnis yang menjanjikan. Hal ini menyebabkan sektor pariwisata memiliki peranan penting dalam pertumbuhan perekonomian suatu negara melalui sumber penerimaan devisa, pendapatan wilayah, pendapatan daerah, penyerapan tenaga kerja dan juga investasi. Berdasarkan data Badan Pusat Statistik jumlah devisa dari sektor pariwisata terus mengalami peningkatan, tercatat pada tahun 2016 devisaIndonesia mencapai 11,206 
Jurnal Pariwisata dan Budaya

Volume 2 Nomor 2 Desember 2021

miliar dolar, lalu pada tahun 2017 mencapai

menyampaikan dalam wawancara pada angka 13,139 miliar dolar dan pada tahun 2018 berada pada angka 16,426 miliar dolar. Daerah Istimewa Yogyakarta adalah salah satu destinasi wisata yang menarik banyak perhatian dan kunjungan wisatawan baik wisatawan domestik maupun mancanegara karena memiliki potensi wisata yang besar berupa wisata alam, budaya, sejarah, kuliner dan lainnya. Dalam laporan Badan Pusat Statistik jumlah total wisatawan yang berkunjung ke Yogyakarta pada tahun 2019 mencapai angka 4.378.609. Angka ini merupakan angka yang besar yang telah menggerakkan perekonomian di Yogyakarta. Pertumbuhan perekonomian ini tidak lepas dari perkembangan sumber daya manusia yang bertahap dan pasti.

Pengembangan sumber daya manusia adalah suatu cara untuk melakukan inovasi, meningkatkan kemampuan yang dimiliki oleh setiap individu untuk pengembangan diri. Pengembangan sumber daya manusia memberikan berbagai dampak positif bagi individu maupun lembaga terkait. Seperti halnya yang terdapat di Pasar Kebon Empring. Pasar Kebon Empring merupakan sebuah pasar tradisional yang bermula adanya musibah badai cempaka. Bapak Isnawan selaku pengelola pasar Kebon Empring tanggal 18 September 2021 bahwa pasar kebon empring bermula karena adanya badai cempaka yang menyebabkan jembatan penghubung antar desa terputus sehingga diperlukan pembuatan jembatan ulang. Dalam pembuatan jembatan tersebut warga berinisiatif untuk memberi kesan yang menarik dengan mengecat jembatan dengan berbagai berwarna sehingga mengundang anak-anak muda untuk melakukan sesi foto atau selfie di jembatan tersebut. Di sekitar jembatan yang digunakan untuk selfie terdapat sebuah kebon empring atau ladang bambu milik warga sekitar serta aliran sungai Gawe yang bersih. Melihat adanya fenomena tersebut maka munculah inisiatif dari warga untuk menjadikan tempat tersebut sebagai tempat wisata. Setelah melakukan musyawarah antar warga dan pemerintah daerah yang berkaitan maka pasar kebon empring diresmikan pada tahun 2018. Peresmian pasar kebon empring yang mengusung konsep tradisional tersebut mendapatkan apresiasi luar biasa dari masyarakat setempat maupun wisatawan yang sudah mulai berdatangan.

Pasar kebon empring merupakan bagian dari destinasi wisata Pokdarwis Desa Srimulyo yang mana hal tersebut memberikan berbagai keuntungan bukan 
Sabbhata Yatra

Jurnal Pariwisata dan Budaya

Volume 2 Nomor 2 Desember 2021

hanya kepada masyarakat namun juga bagi

kegiatan pariwisata. Bapak Isnawan lingkungan. Hal tersebut dapat dilihat menyampaikan dalam wawancara pada bahwa Pasar Kebon Empring yang berada di hutan bambu dengan aliran sungai di sekitarnya menjadikan pengelola senantiasa menjaga dan membersihkan sampah untuk tetap menjaga kelestariannya. Selain itu pasar kebon empring yang semakin berkembang juga menawarkan hal-hal berbau modern seperti menampilkan musik, bukan hanya itu pasar kebon empring juga menampilkan budaya-budaya daerah setempat. Perpaduan antara alam dan budaya menjadikan pasar kebon empring banyak dikunjungi oleh wisatawan untuk menikmati wisata alam yang mana dapat memberikan rasa rileks atau nyaman kepada pengunjung yang berdatangan.

Perkembangan sebuah destinasi wisata dalam hal ini adalah Pasar Kebon Empring tidak lepas dari sumber daya manusianya. Masyarakat setempat diajak bekerja sama dan gotong royong untuk melakukan kegiatan wisata. Masyarakat yang pada mulanya tidak mengetahui cara untuk menjalankan wisata tetap semangat menyambut hal tersebut. Masyarakat di desa Bintaran yang banyak diantaranya adalah ibu rumah tangga yang menjalankan pariwisata dengan berdagang di pasar kebon empring tersebut belum sepenuhnya melakukan pelatihan-pelatihan dalam

tanggal 18 September 2021 bahwa masyarakat maupun pengelola Pasar Kebon Empring belum mendapatkan pelatihan untuk pengembangan sumber daya manusia. Melihat hal tersebut penulis dalam hal ini memiliki pemikiran dalam rangka menganalisis kebutuhan apa saja yang dibutuhkan oleh masyarakat maupun pengelola Pasar Kebon Empring dalam rangka melakukan pengembangan destinasi wisata. Berbagai cara dapat digunakan dalam rangka melakukan pengembangan sumber daya manusia yang diharapkan mampu memberikan ilmu atau pengetahuan dalam mengembangkan kompetensi individu untuk pengelolaan sebuah destinasi wisata.

Pasar Kebon Empring merupakan destinasi wisata yang menawarkan kuliner tradisional yang dikelola oleh masyarakat Bintaran Wetan, Desa Srimulyo, Piyungan, Bantul, Yogyakarta. Masyarakat bekerja bersama-sama untuk mengelola pasar kuliner ini dimulai dari perencanaan hingga pelaksanaan. Dalam perkembangannya untuk menjadi pasar kuliner yang diminati banyak pengunjung diperlukan adanya berbagai macam keahlian yang sesuai dengan kebutuhan pasar sehingga diperlukan adanya analisis mengenai 
Jurnal Pariwisata dan Budaya

Volume 2 Nomor 2 Desember 2021

kebutuhan apa yang diperlukan untuk

Sutrisno, Wiriadi et al (2016)

meningkatkan kualitas pelayanan. Pasar

Kebon Empring merupakan destinasi wisata baru yang dikelola oleh masyarakat Bintaran Wetan, Desa Srimulyo, Piyungan, Bantul, Yogyakarta. Tujuan penulisan paper ini adalah untuk mengetahui kebutuhan apa saja yang diperlukan dalam mengembangkan pariwisata di Pasar Kebon Empring menggunakan analisis SWOT dengan menerapkan strategi Training Needs Assessment.

\section{METODE}

Penelitian ini menggunakan objek sebuah pasar kuliner yang menjadi destinasi wisata yaitu Pasar Kebon Empring dengan menggunakan metode studi dokumen. Data diperoleh dari studi dokumen melalui informasi di internet dan juga melalui wawancara dengan pengelola Pasar Kebon Empring yaitu Bapak Isnawan pada 18 September 2021. Penelitian dilakukan dengan melakukan pengumpulan data, klasifikasi data, analisis dan penarikan kesimpulan. Hasil analisis data kemudian disajikan secara deskriptif.

\section{HASIL PENELITIAN DAN PEMBAHASAN}

Hasil Penelitian 
Jurnal Pariwisata dan Budaya

Volume 2 Nomor 2 Desember 2021

operasi atau kegiatan di tempat kerja, perlunya perencanaan dan penyusunan alur kerja, penjagaan catatan tempat kerja serta pemecahan masalah dan pembuatan keputusan.

Barbazette (2006) menyatakan bahwa training needs assessment adalah sebuah proses mengumpulkan informasi tentang pengalaman atau kebutuhan organisasi yang tersirat yang dapat dipenuhi dengan melakukan pelatihan. Penilaian kebutuhan dalam sebuah organisasi penting dilakukan untuk mengatasi permasalahan atau menjadi solusi yang sesuai dalam memecahkan permasalahan yang dihadapi oleh sebuah organisasi.

Dalam memberikan penilaian training needs assessment terdapat berbagai langkah yang perlu diperhatikan. Barbazette (2006) juga menyampaikan langkahlangkah yang perlu dilakukan dalam melakukan penilaian, diantaranya adalah sebagai berikut: (1) Mengumpulkan informasi. Pengumpulan informasi dilakukan untuk membantu membuat keputusan yang sesuai dan tepat. Proses pengumpulan informasi dapat berupa mengumpulkan informasi yang sudah ada atau mengembangkan informasi yang baru; (2) Menganalisis informasi. Setelah dilakukannya pengumpulan informasi maka perlu dilakukan analisa, menafsirkan dan menarik kesimpulan dari informasi yang telah didapatkan.; dan (3) Membuat rencana pelatihan. Setelah dilakukan analisis dan menafsirkan informasi serta mengambil keputusan, maka dapat melakukan perencanaan pelatihan untuk mengatasi kekurangan kinerja dalam sebuah organisasi.
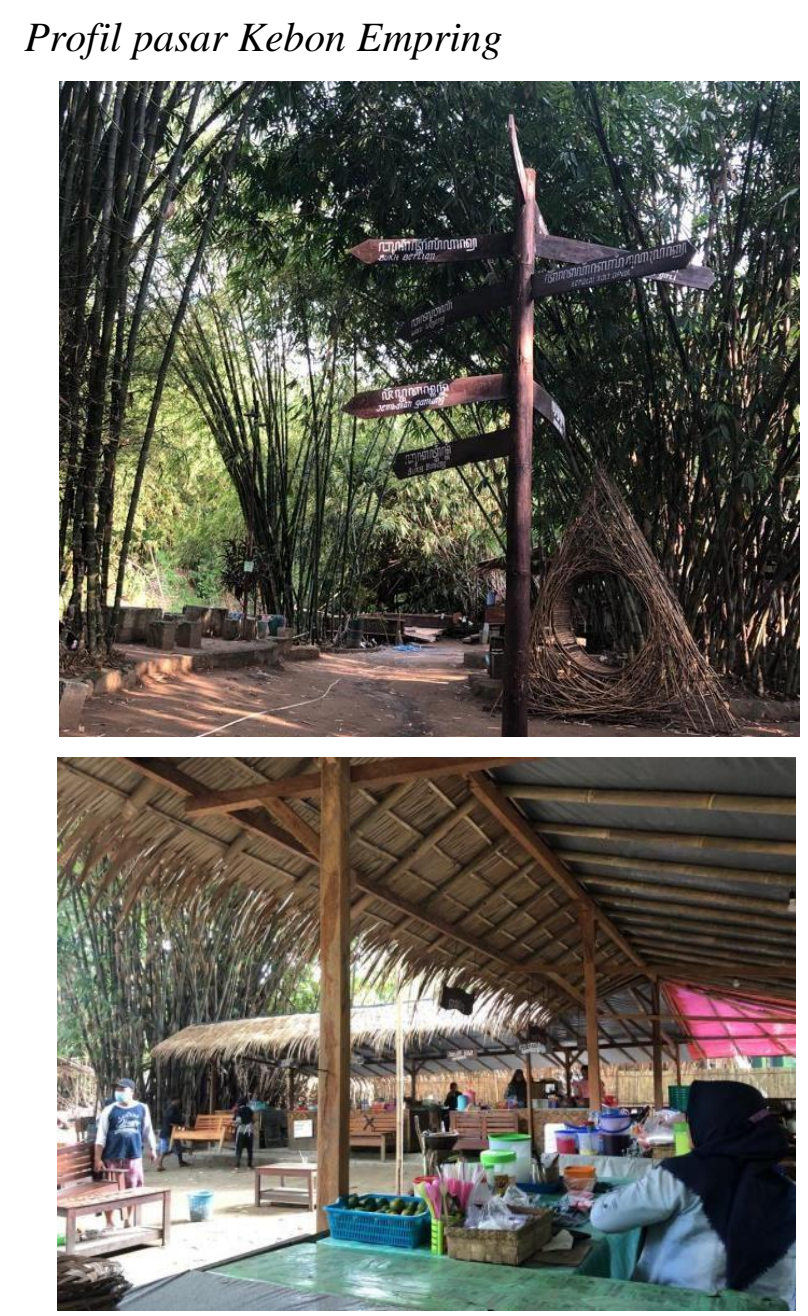

Sumber: Dokumentasi penulis, 2021

Pasar Kebon Empring merupakan sebuah destinasi wisata baru yang menawarkan aneka kuliner yang berada di 
Padukuhan Bintaran Wetan, Desa Srimulyo, Piyungan, Bantul, Yogyakarta. Keunikan pasar ini adalah lokasinya yang berada di tengah-tengah kebun bambu yang dalam Bahasa Jawa disebut empring. Pasar ini buka setiap hari pukul 06.00-18.00. Para penjual atau pelapak merupakan warga desa Bintaran Wetan yang menjual aneka makanan tradisional seperti lotek, gadogado, tahu gejrot, es dawet, es tebu, dan lain sebagainya. Setiap pelapak diwajibkan untuk membayar iuran sebesar Rp 5.000 per hari untuk biaya sewa tempat selain itu terdapat aturan bagi para pedagang yang harus menjual makanan dan minuman berbeda agar menu yang dijual beragam serta untuk mengurangi persaingan antar pedagang.

Pengelola Pasar Kebon Empring memanfaatkan bambu-bambu sebagai daya tarik pasar ini dengan memanfaatkannya sebagai meja dan kursi untuk tempat makan pengunjung, spot foto, bahan untuk membuat mushola, serta bahan untuk cinderamata yang dibuat oleh masyarakat Bintaran Wetan. Selain letaknya yang berada di tengah hutan bambu pasar ini juga terletak dipinggir sungai Gawe yang kemudian dimanfaatkan oleh pihak pengelola untuk dijadikan tempat makan dengan meletakkan meja dan kursi di sungai sehingga para pengunjung dapat merasakan suasana desa yang asri dengan makan diatas sungai, mencari ikan serta berenang untuk pengunjung. Untuk mengantisipasi kejadian yang tidak diinginkan pihak pengelola memberi tanda atau batas maksimal pengunjung dapat bermain air di sungai.

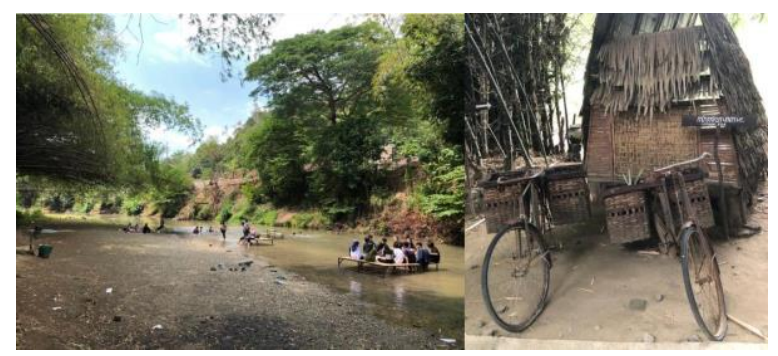

Sumber: Dokumentasi penulis, 2021

Pasar Kebon Empring diawali dengan adanya bencana banjir pada tahun 2018 yang menghanyutkan jembatan yang menghubungkan dua desa, warga kemudian membangun jembatan gantung yang kemudian menjadi destinasi wisata baru yang digunakan oleh warga untuk berfoto. Melihat potensi ini kemudian muncul gagasan untuk membuat pasar Ramadhan karena bertepatan dengan bulan puasa. Lokasi pasar ini memanfaatkan lahan milik warga dengan sistem sewa yang akan mendapatkan bayaran setiap bulan.

Untuk masuk ke pasar ini pengunjung masuk dengan dana sukarela atau belum ada retribusi yang harus dibayarkan kepada pengelola. Dalam mengembangkan wisatanya pihak pengelola mengembangkan aspek 3 A yaitu atraksi, amenitas, dan 
Jurnal Pariwisata dan Budaya

Volume 2 Nomor 2 Desember 2021

aksesibilitas. Daya tarik utama dari pasar ini adalah kulinernya yang semakin beragam dengan adanya 32 pelapak yang terdiri dari 27 pelapak yang menjual makanan dan minuman tradisional yang berbeda dan 5 pelapak yang menjual cinderamata. Dari segi amenitas pihak pengelola telah menyiapkan berbagai macam fasilitas mulai dari toilet, tempat parkir, tempat duduk, spot foto, panggung hiburan, dan mushala. Dari segi aksesibilitas, pasar ini dapat diakses dengan cukup mudah dengan adanya signage atau papan penunjuk jalan mulai dari Jalan Raya Wonosari hingga menuju area parkir pasar ini. Akses jalan sudah cukup bagus dengan kondisi jalan yang sudah dicor dan menggunakan sistem jalan satu arah karena jalan hanya cukup dilewati 1 kendaraan roda empat. Selain itu pasar ini sudah memiliki sosial media instagram dengan nama @pasarkebonempring yang membagikan berbagai informasi tentang pasar ini.

\section{Pembahasan}

Training needs assessment menurut Brown (2002) "is an ongoing process of gathering data to determine what training needs exists so that training can be developed to help the organization accomplish its objectives" ( merupakan sebuah proses pengumpulan data untuk menentukan pelatihan yang diperlukan untuk membantu organisasi untuk mencapai tujuannya). Training needs assessment merupakan salah satu strategi yang harus dimiliki setiap organisasi atau lembaga dalam menjalankan rute organisasi. Strategi yang dijalankan menentukan perkembangan dari organisasi atau lembaga berkaitan dengan analisis kebutuhan sumber daya manusia yang berperan sebagai pegawai atau pekerja dalam organisasi terkait. Analisis kebutuhan dalam organisasi perlu dilakukan secara rinci dan matang sehingga tidak terjadi surplus maupun kekurangan pegawai yang diakibatkan karena tidak ada analisis kebutuhan yang sesuai. Berbagai strategi training needs assessment banyak ditemukan dalam rangka menganalisis kebutuhan dalam setiap organisasi, namun dalam hal ini penulis bermaksud menganalisis kebutuhan Pasar Kebon Empring menggunakan Training Needs Assessment yang telah disebutkan oleh Barbazette (2006) yang mana terdiri dari tahap menemukan informasi, menganalisis informasi serta perencanaan kebutuhan pelatihan. Analisis dalam tulisan ini dijabarkan sebagai berikut:

(1) Menemukan informasi. Dalam menemukan informasi, peneliti telah melakukan observasi di Pasar Kebon Empring pada tanggal 18 September 2021. 
Jurnal Pariwisata dan Budaya

Volume 2 Nomor 2 Desember 2021

Dalam pelaksanaan observasi, penulis juga

setempat. Produk lain yang ditawarkan melaksanakan proses wawancara dengan salah satu pengelola pasar kebon empring yaitu Bapak Isnawan. Pengumpulan data yang dilakukan oleh penulis dengan melakukan pengamatan dan wawancara dengan pengelola Pasar Kebon Empring. Dikatakan bahwa pedagang yang berjualan di dalam area pasar kebon empring adalah masyarakat setempat yang mengikuti kelompok Pokdarwis Desa Srimulyo. Masyarakat masih belum secara menyeluruh mengetahui bagaimana cara mengelola destinasi wisata. Bapak Isnawan menyampaikan bahwa yang penting di awal pembentukan Pasar Kebon Empring adalah masyarakat setempat bisa melakukan kegiatan berdagang dan menyajikannya dengan baik dalam melayani wisatawan (wawancara 18 September 2021). Konsep yang diusung pada pasar kebon empring adalah pasar tradisional dengan nuansa alamnya. Hal tersebut dapat dilihat dari lokasi destinasi wisata, pakaian yang digunakan penjual hingga makanan yang disajikan. Produk yang ditawarkan di Pasar Kebon Empring tersebut masih tergolong sederhana dengan memiliki perbedaan pada setiap stand atau lapak yang ditawarkannya. Produk seperti makanan yang ditawarkan adalah makanan yang sudah jarang ditemui seperti makanan-makanan tradisional seperti alat permainan anak-anak adalah alat permainan tradisional yang sudah jarang ditemui dan dimainkan. Permainan tersebut diantaranya adalah egrang, jungkat-jungkit, congklak, dan lain sebagainya. Banyaknya produk tersebut menarik para wisatawan untuk bermain dan menambah pengalaman. Namun dalam mengikuti perkembangan saat ini diperlukan perkembangan produk-produk. Pengembangan produk memang perlu dilakukan sehingga produk yang ditawarkan tidak terlihat monoton. Para winisatawan atau host pasar kebon empring juga belum secara menyeluruh menggunakan perlengkapan teknologi. Hal ini dibuktikan dengan pembayaran dalam membeli makanan masih dilakukan secara manual yaitu membayar dengan uang secara langsung. Penggunaan teknologi informasi yang masih kurang dapat menentang tujuan dari Pasar Kebon Empring sendiri yang mengusung konsep tradisional. Namun hal tersebut tidak secara gamblang dibenarkan mengingat bahwa saat ini memasuki era digital yang mana segala sesuatu dapat dilakukan secara online, baik pembelian tiket hingga pembayaran pembelian sebuah produk. Selain hal itu para pedagang yang berjualan di pasar Kebon Empring juga belum mendapatkan pelatihan-pelatihan. 
Jurnal Pariwisata dan Budaya

Volume 2 Nomor 2 Desember 2021

Sehingga masyarakat setempat masih menjalankannya dengan cara yang sederhana dengan pengetahuan dasar yang diketahuinya saja. Melihat kondisi tersebut maka dapat diambil keputusan bahwa kurangnya pelatihan yang diterima oleh para winisatawan menjadikan kurangnya pengetahuan baik dalam menyajikan produk maupun memberikan pelayanan terhadap wisatawan. Perlunya analisis kebutuhan untuk pelatihan dalam rangka mengetahui kebutuhan apa saja yang diperlukan oleh winisatawan dalam mengembangkan kompetensi diri dalam pengembangan sebuah destinasi wisata.

(2) Menganalisis informasi. Dalam menganalisis informasi yang telah didapatkan melalui wawancara dengan Bapak Isnawan selaku pengelola Pasar Kebon Empring dan pengamatan atau studi dokumen penulis menggunakan analisis SWOT yaitu Strength, Weakness, Opportunity, dan Threats di Pasar Kebon Empring. Analisis SWOT digunakan oleh penulis untuk mempermudah dalam pengelompokan serta menganalisis apa saja informasi yang telah penulis dapatkan dalam proses pengamatan serta studi dokumen.

\section{Strength}

a. Pasar kebon empring buka setiap hari dari pukul 06.00 - 18.00 WIB;

b. Makanan yang ditawarkan berbeda dari setiap kedai, sehingga wisatawan memiliki beragam pilihan;

c. Konsep yang digunakan adalah bernuansa alam yang berlokasi di hutan bambu serta berada di pinggir sungai Gawe yang dapat dimanfaatkan sebagai tempat makan dan arena bermain dalam rangka menambah pengalaman terutama bagi anak-anak;

d. Kemudahan promosi dengan adanya digitalisasi.

\section{Weakness}

a. Belum adanya pelatihan memasak bagi para pelapak kuliner;

b. Belum ada tempat makan tertutup sehingga saat hujan para wisatawan tidak dapat makan ditempat yang teduh;

c. Belum adanya pelatihan pelayanan bagi para pelaku usaha dan pihak pengelola;

d. Belum adanya retribusi yang tetap, seperti tiket masuk maupun biaya parkir;

e. Kurangnya kerjasama dengan pemerintah dan usaha pariwisata;

f. Kurang aktif melakukan promosi melalui sosial media. 


\section{Opportunity}

a. Menjadi destinasi wisata kuliner pilihan yang dapat dikunjungi setiap hari;

b. Potensi alam yang masih dapat digali kembali oleh pengelola;

c. Kekompakan dan semangat dari pengelola dan masyarakat sekitar dalam melaksanakan pengembangan destinasi wisata;

d. Pangsa pasar yang menjanjikan;

e. Menjadi destinasi wisata kuliner diantara destinasi wisata lain di Desa Srimulyo;

f. Terdapat peternakan kambing yang dapat dimanfaatkan untuk wisata edukasi.

\section{Threats}

a. Saat musim hujan terjadi penurunan kunjungan karena tidak adanya ruangan tertutup;

b. Munculnya destinasi wisata kuliner baru;

c. Suasana yang monoton, sehingga perlu dilakukan inovasi baru;

d. Apabila di musim penghujan perlunya meningkatkan kewaspadaan yang disebabkan adanya dampak arus air sungai yang tidak dapat diperhitungkan;

e. Over carrying capacity;

f. Kerusakan alam yang disebabkan sampah dari wisatawan;

g. Cita rasa makanan yang tidak dikembangkan.

Analisis SWOT berdasarkan hasil wawancara dan studi dokumen Pasar Kebon Empring

(3) Membuat rencana pelatihan. Setelah dilakukannya berbagai langkah dalam melaksanakan training needs assessment hingga sampai pada menganalisis informasi yang telah didapatnya, maka langkah selanjutnya yang perlu dilakukan adalah membuat rencana pelatihan. Perencanaan pelatihan dalam rangka pemenuhan kebutuhan pada Pasar Kebon Empring diantaranya adalah : Melaksanakan pelatihan pelayanan prima bagi wisatawan; Melaksanakan pelatihan memasak dalam pemenuhan kebutuhan kuliner; Melaksanakan pelatihan dalam pengelolaan sebuah destinasi wisata; Melaksanakan pendampingan kepada masyarakat dan pengelola dalam rangka menggali potensi pariwisata baru; Melaksanakan pendampingan kepada generasi muda agar mau dan mampu tampil serta mengikuti kegiatan pariwisata setempat; Melaksanakan komunikasi yang intensif dengan Pemerintah setempat dalam rangka pelatihan mitigasi bencana; Mengadakan studi banding ke tempat wisata lain untuk 
Jurnal Pariwisata dan Budaya

Volume 2 Nomor 2 Desember 2021

meningkatkan inovasi dan kreatifitas; dan melaksanakan pelatihan promosi wisata dengan memanfaatkan teknologi informasi seperti sosial media.

\section{PENUTUP}

Dalam mengembangkan potensi wisata di Pasar Kebon Empring untuk menjadi destinasi wisata yang diminati pengunjung diperlukan berbagai macam keahlian. Penulis menggunakan strategi Training Need Assessment yang dikemukakan oleh Barbazette (2006) dengan tiga tahapan yaitu;1. Pengumpulan informasi yang dilakukan dengan wawancara dengan pihak pengelola dan studi dokumen, 2 . Analisis informasi menggunakan analisis SWOT (Strength, Weakness, Opportunity, Threats), dan 3. Menentukan rencana pelatihan. Hasil analisis menunjukkan bahwa Pasar Kebon Empring memerlukan adanya pelatihan layanan prima bagi wisatawan, pelatihan memasak, pelatihan pengelolaan destinasi wisata, pendampingan dan pelatihan dalam menggali potensi wisata baru, pendampingan kepada pemuda untuk ikut dalam kegiatan pariwisata, pelatihan serta komunikasi dengan pemerintah terkait mitigasi bencana, studi banding ke tempat wisata dalam rangka meningkatkan inovasi dan kreatifitas, dan pelatihan promosi wisata dengan memanfaatkan teknologi informasi.

\section{REFERENCES}

Brown, J. (2002). Training Needs Assessment: A Must for Developing an Effective Training Program. Public Personnel Management Volume 31 No. 4 Winter 2002, 569-578.

Barbazette, J. (2006). Training Needs Assessment: Methods, Tools, and Techniques. Library of Congress Cataloging in Publication Data: Pfeiffer.

Sutrisno, dkk. (2016). Analisis Pelatihan dan Pendampingan Potensi Sosek Melalui Pendekatan Training Need Assesment di Kobalima Timur, Provinsi NTT. Journal of Applied Business and Economics, Volume 3, No.2, 103-117.

Nggini, Yulius Habita. (2019). Analisis SWOT (Strength, Weakness, Opportunity, Threats) Terhadap Kebijakan Pengembangan Pariwisata Provinsi Bali. Jurnal Ilmiah Dinamika Sosial. Volume 3, No.1, 141-152.

Sutrisno, dkk. (2016). Analisis Penerapan Hospitality, Hygiene dan Sanitasi Pada Usaha Kuliner di Kawasan Wisata Setu Babakan di Jagakarsa, Jakarta Selatan. Journal of Applied Business and Economics, Volume 2 No.3, 260270.

Andriani, dkk. (2019). Analisis Kebutuhan Pelatihan Pengembangan Keprofesian Berkelanjutan di PPPPTK Bisnis dan Pariwisata.Jurnal Pembelajaran Inovatif.Volume 2, Nomor 2, 150161.

Badan Pusat Statistik. 2020. Jumlah Devisa Sektor Pariwisata. 
Jurnal Pariwisata dan Budaya

Volume 2 Nomor 2 Desember 2021

Anonim. 2021. Wisata Kebon Empring:

pasar-kebon-empring-piyungan-

Kulineran di Aliran Sungai dan bantul/ diakses pada 1 Desember Hutan Bambu. 2021

https://travel.tempo.co/read/1466877/wisata -di-pasar-kebon-empringkulineran-di-aliran-sungai-danhutan-bambu diakses pada 1 Desember 2021.

Anonim. 2019. Wisata Kuliner Sembari Nikmati Alam di Pasar Kebon Empring Piyungan Bantul

https://joglosemarnews.com/2019/03/wisata -kuliner-sembari-nikmati-alam-di- 